\title{
Exogenous Enzymes Influenced Eimeria-Induced Changes in Cecal Fermentation Profile and Gene Expression of Nutrient Transporters in Broiler Chickens
}

\author{
Yang Lin and Oluyinka A. Olukosi *(D) \\ Department of Poultry Science, University of Georgia, Athens, GA 30602, USA; Yang.Lin@uga.edu \\ * Correspondence: oaolukosi@uga.edu; Tel.: +1-706-542-1359
}

check for

updates

Citation: Lin, Y.; Olukosi, O.A. Exogenous Enzymes Influenced Eimeria-Induced Changes in Cecal Fermentation Profile and Gene Expression of Nutrient Transporters in Broiler Chickens. Animals 2021, 11, 2698. https://doi.org/10.3390/ ani11092698

Received: 19 August 2021

Accepted: 13 September 2021

Published: 15 September 2021

Publisher's Note: MDPI stays neutral with regard to jurisdictional claims in published maps and institutional affiliations.

Copyright: (c) 2021 by the authors. Licensee MDPI, Basel, Switzerland. This article is an open access article distributed under the terms and conditions of the Creative Commons Attribution (CC BY) license (https:// creativecommons.org/licenses/by/ $4.0 /)$.
Simple Summary: Eimeria-induced coccidiosis, a common disease in the poultry industry, causes substantial economic loss globally. The developed resistance to synthetic anticoccidial drugs and increasing public and legislative pressures to decrease antibiotic utilization drive research exploring non-antibiotic alternatives to control coccidiosis. Two experiments were conducted to investigate the potential mechanisms by which enzymes may mitigate the negative effects of Eimeria on growth performance, nutrient-transporter gene expression, and cecal fermentation patterns. The results demonstrated that Eimeria changed the expression of tight junctions and nutrient transporters genes, promoted cecal protein fermentation, and inhibited cecal saccharolytic fermentation. Exogenous xylanase and protease supplementation alleviated negative effects of Eimeria effects on the above responses, and thus demonstrated benefits of enzyme supplementation beyond improvement in nutrient utilization.

Abstract: Two 21-day experiments were conducted to investigate the effects of exogenous enzymes on growth performance, tight junctions, and nutrient transporters, jejunal oligosaccharides and cecal short-chain fatty acids (SCFA) of broiler chickens challenged with mixed Eimeria. Two different basal diets: high fiber-adequate protein (HFAP; Expt. 1) or low fiber-low protein (LFLP; Expt. 2) were used in the two experiments. In each experiment, birds were allocated to four treatments in a $2 \times 2$ factorial arrangement (with or without protease and xylanase combination; with or without Eimeria challenge). In Expt. 1, with HFAP diets, Eimeria upregulated $(p<0.05)$ the expression of claudin-1, but downregulated $(p<0.05)$ glucose transporters GLUT2/GLUT5. On the contrary, enzymes downregulated $(p<0.05)$ claudin-1 and alleviated the Eimeria-depressed GLUT2/GLUT5 expression. In both experiments, Eimeria decreased $(p<0.05)$ cecal saccharolytic SCFA and increased $(p<0.05)$ cecal branched-chain fatty acids. The challenge $\times$ enzyme interaction $(p<0.05)$ showed that enzymes reversed the Eimeria effects on fermentation pattern shift. In conclusion, Eimeria altered tight junctions and nutrient transporters expression promoted cecal proteolytic fermentation and inhibited saccharolytic fermentation. Exogenous enzymes showed the potential of alleviating the Eimeriainduced intestinal gene expression changes and reversing the unfavorable cecal fermentation pattern.

Keywords: xylanase; protease; Eimeria; short-chain fatty acid; cecal fermentation; tight junctions; nutrient transporter; broiler chicken

\section{Introduction}

Avian coccidiosis is a worldwide disease that is caused by protozoan parasites of Eimeria spp. Seven species of Eimeria including E. acervuline, E. brunetti, E. maxima, E. mitis, E necatrix, E. praecox, and E. tenella have been identified in the broiler chicken industry [1]. The prevalence of coccidiosis usually occurs with a mixed infection instead of a single species with the mixed infection by E. acervulina, E. maxima, and E. tenella being more prevalent [2]. These three species of Eimeria spp. preferentially invade and multiply in the 
regions of duodenum, jejunum plus ileum, and ceca, respectively; however, intersectional infection also can be observed [3].

Damage to gastrointestinal epithelial cells resulting in depressed nutrient utilization and growth performance in birds leads to USD 14.5 billion losses annually in poultry production due to coccidiosis [4,5]. Eimeria-induced gastrointestinal damage is also considered to influence the regulation of intestinal tight junctions and nutrient transporters. The changes to intestinal nutrient transporters including sugars, amino acids, and mineral transporters may partly contribute to the Eimeria-induced growth depression [6,7]. In addition, it has been demonstrated that Eimeria infection impacted the microbial population and composition in the hindgut of broiler chickens, resulting in cecal dysbacteriosis. The infection decreased the abundance of beneficial bacteria such as carbohydrate-fermenting Ruminococcaceae, butyrate-producing Faecalibacterium, and probiotic bacterium Lactobacillus, whereas enriched opportunistic pathogenic bacteria of the genera Enterococcus and Streptococcus [8]. The dysbacteriosis in the hindgut indicates a shift of fermentation patterns in ceca.

Anticoccidial drugs and live vaccines have been applied in the commercial poultry industry as conventional methods to prevent coccidiosis. However, after exposure to antibiotics for decades, Eimeria spp. have developed resistance to these synthetic anticoccidial drugs whereas vaccines are costly for production and storage [9]. In view of the need for alternatives to antibiotics, dietary antibiotic alternatives are possible options to help treat or prevent coccidiosis. Probiotics such as Lactobacillus-based probiotic, Pediococcus acidilactici-based probiotic, and B. subtilis-based probiotics have shown positive results in enhancing mucosal immunity, lessening Eimeria-induced growth depression, and improving resistance to Eimeria infection [10-12]. Prebiotics with the ability to maintain intestinal flora balance has also shown promise by enriching beneficial bacteria [12].

It has been reported that the effects of prebiotic and carbohydrase supplementation on the performance of broilers challenged with coccidia are similar, supporting the hypothesis that oligosaccharides are released from carbohydrase-degraded non-starch polysaccharides and play prebiotic roles in birds' gastrointestinal tract [13-15]. In a previous study with supplementation of protease alone or in combination with carbohydrases, the effects of enzymes on the disappearance of non-starch polysaccharides in digesta and accumulation of lower molecular weight carbohydrates were similar [16]. In view of the potential effects of enzyme supplementation and dietary fiber profile affecting the generation of prebiotic substances in the digestive tract of birds [17], there is a possibility of these factors having positive effects on the intestinal milieu of broiler chickens challenged with coccidiosis. Consequently, two experiments were conducted to investigate the potential and mechanism of enzymes on mitigating the negative effects of Eimeria challenge on growth performance, gene expression of nutrient transporters, and cecal fermentation patterns. A two-diet model, high fiber-adequate protein, and low fiber-low protein were chosen from previous work [17], where xylanase and protease showed effects on digesta concentration of oligosaccharides and cecal short-chain fatty acids (SCFA). Consequently, these diets were used separately in the current experiment because their interactions in a factorial treatment arrangement setting have been demonstrated previously [17].

\section{Materials and Methods}

\subsection{Animals, Diets Experimental Design and Eimeria Challenge}

One hundred and twenty zero-day-old Cobb 500 male broiler chicks were used in each of the two $21 \mathrm{~d}$ experiments. A basal diet, formulated to have a high level of fiber and adequate protein (HFAP), was used in Expt. 1, whereas the basal diet in Expt. 2 was formulated to have a low level of fiber and lower than recommended protein level (LFLP). Each of the experiments had four treatments in a $2 \times 2$ factorial arrangement. The factors were enzyme supplementation (with or without a combination of xylanase and protease) and Eimeria challenge (with or without). The birds in all the treatments in each experiment had the same initial body weight (day 0 ). Each of the four treatments had six replicate 
cages and five birds per replicate cage. Light was provided for $24 \mathrm{~h}$ on the first three days and gradually decreased to $8 \mathrm{~h}$ dark period on the last day. The room temperature was set at $33{ }^{\circ} \mathrm{C}$ and gradually decreased to $25^{\circ} \mathrm{C}$ during the rearing period. Temperature and humidity were recorded daily.

The basal diets were corn-soybean meal-based, and wheat plus wheat bran was used as a fiber provider in the HFAP diet, producing a slightly lower AME level in Expt. 1 diet. The low-protein diets used in Expt. 2 had three percentage points lower crude protein levels compared with adequate protein diets. Five hundred FTU/kg phytase (Quantum Blue, AB Vista, Marlborough, UK; 5000 FTU/g) was supplemented in all the diets. Each basal diet was divided into two experimental diets: control diet (without enzyme supplementation), or supplemented with a combination of $0.2 \mathrm{~g} / \mathrm{kg}$ mono-component protease and $0.1 \mathrm{~g} / \mathrm{kg}$ of xylanase (XP). The $\beta$-(1-4)-endo-xylanase was from genetically modified Trichoderma reesei. The serine protease was produced by the sporulation-deficient Bacillus licheniformis strain. Birds receiving each of the two experimental diets were allocated equally into two groups gavaged with $1 \mathrm{~mL}$ distilled water or $1 \mathrm{~mL}$ mixed-species Eimeria oocysts solution on day 15 . The mixed-species Eimeria spp. water-based solution containing 12,500 oocysts of E. maxima, 12,500 oocysts of E. tenella, and 62,500 oocysts of E. acervuline per $1 \mathrm{~mL}$ was prepared for a mild infection challenge. The ingredient composition of the basal diets is presented in Table 1 and the analyzed chemical composition of the experimental diets is presented in Table 2. The analyzed enzyme activities were, on average 311,9500, and 18,700 units per kg for phytase, xylanase, and protease, respectively. The analyzed activities were $62 \%, 56 \%$, and $124 \%$ of expected activities for phytase, xylanase, and protease, respectively.

Table 1. Ingredient compositions $(\mathrm{g} / \mathrm{kg})$ of the experimental basal diets.

\begin{tabular}{ccc}
\hline Items & Expt. 1 (HFAP) & Expt. 2 (LFLP) \\
\hline Corn & 300 & 655 \\
Wheat & 200 & 0 \\
Wheat bran & 100 & 0 \\
Soybean meal & 310 & 260 \\
Soybean oil & 40 & 35 \\
Titanium dioxide & 5.0 & 5.0 \\
Di-calcium phosphate & 8.9 & 8.9 \\
Limestone & 15.6 & 15.6 \\
Lysine & 4.2 & 4.2 \\
Methionine & 3.4 & 3.4 \\
Threonine & 2.6 & 2.6 \\
NaHCO 3 & 2.0 & 2.0 \\
Salt & 3.5 & 3.5 \\
Vitamin premix ${ }^{1}$ & 2.5 & 2.5 \\
Trace minerals premix ${ }^{2}$ & 2.5 & 2.5 \\
Phytase & 0.1 & 0.1 \\
Total & 1000 & 1000 \\
\hline & Calculated Nutrients and Energy, g/kg & \\
\hline CP & 211 & 181 \\
ME, kcal/kg & 2752 & 2988 \\
Ca & 9.5 & 9.2 \\
Total P & 6.0 & 5.0 \\
Available P & 2.8 & 2.7 \\
Met & 6.5 & 6.3 \\
Cys & 3.5 & 3.1 \\
Met + Cys & 10.0 & 9.4 \\
Lys & 5.5 & 4.9 \\
His & &
\end{tabular}


Table 1. Cont.

\begin{tabular}{ccc}
\hline Items & Expt. 1 (HFAP) & Expt. 2 (LFLP) \\
\hline Trp & 2.6 & 2.0 \\
Thr & 10.3 & 9.4 \\
Arg & 14.0 & 11.7 \\
\hline
\end{tabular}

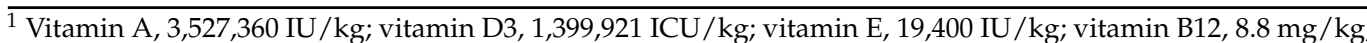
menadione, $1102 \mathrm{mg} / \mathrm{kg}$; riboflavin, $3527 \mathrm{mg} / \mathrm{kg}$; d-pantothenic acid, $5467 \mathrm{mg} / \mathrm{kg}$; thiamine, $970 \mathrm{mg} / \mathrm{kg}$; niacin, $20,282 \mathrm{mg} / \mathrm{kg}$; vitamin B6. $1455 \mathrm{mg} / \mathrm{kg}$; folic acid, $573 \mathrm{mg} / \mathrm{kg}$; biotin, $79 \mathrm{mg} / \mathrm{kg}$. $\mu$ g. ${ }^{2}$ Calcium, $3.20-4.20 \%$; manganese $13.40 \%$; Zinc, $10.70 \%$; magnesium, 2.68\%; iron, 2.63\%; copper, 40,000 ppm; iodine, $1000 \mathrm{ppm}$; selenium, 400 ppm. ${ }^{3}$ Available P level included the matrix for the phytase. $\mathrm{CP}$-crude protein; AP—adequate protein; LP-low protein; HF-high fiber; LF-low fiber.

Table 2. Analyzed composition $(\mathrm{g} / \mathrm{kg})$ of experimental diets.

\begin{tabular}{ccc}
\hline Items & Expt. 1 (HFAP) & Expt. 2 (LFLP) \\
\hline Dry matter & 901 & 895 \\
Crude protein & 204 & 172 \\
Calcium & 8.66 & 10.21 \\
Total Phosphorus & 4.22 & 7.25 \\
Acid detergent fiber & 38.1 & 32.0 \\
Neutral detergent fiber & 138 & 88.0 \\
(Hex)3 & 44.7 & 34.7 \\
(Hex)4 & 58.8 & 38.2 \\
(Hex)5 & 1.54 & 1.14 \\
(Hex)6 & 0.14 & 0.34 \\
(Pent)3 & 0.09 & $\mathrm{ND}$ \\
(Pent)5 & 0.31 & 0.13
\end{tabular}

Hex-hexose; Pent—pentose; ND—not detected; AP—adequate protein; LP—low protein; HF—high fiber LF-low fiber. (Pent) 4 and (Pent) 6 were not detected in diets.

\subsection{Growth Performance, Intestinal Permeability, and Lesion Scoring}

All animal experiment procedures were approved by the Institutional Animal Care and Use Committee at the University of Georgia, Athens, Georgia, USA (Protocol No: A2018-08-026). Birds and feed were weighed on d 0, 15, and 21. Mortality was monitored daily and used to calculate mortality-adjusted weight gain (WG), feed intake (FI), and gain: feed ratio. The intestinal permeability test was conducted on $\mathrm{d} 19,5 \mathrm{~d}$ post infection (DPI). A $2.2 \mathrm{mg} / \mathrm{mL}$ fluorescein isothiocyanate dextran (FITC-d, MW 4000; Sigma-Aldrich, St. Louis, MO, USA) solution was prepared right before the test. One bird was randomly selected from each of the challenged group cages and orally gavaged with $1 \mathrm{~mL}$ FITC-d solution. Birds from unchallenged and no-enzyme treatment were also administrated with FITC-d as the control group. Blank blood sample from extra birds (provided with standard broiler feed) was collected to dilute FITC-d to prepare solutions for the standard curve. After $2 \mathrm{~h}$ of administration, birds were euthanized and blood samples were collected from the heart and pooled by treatment. Clotted blood was centrifuged at $1000 \times g$ for $12 \mathrm{~min}$ to separate the serum. The serum sample and standard solutions were measured by a spectrophotometer (Spectramax M5, Molecular Devices, San Jose, CA, USA) at an excitation wavelength of $485 \mathrm{~nm}$ and an emission wavelength of $528 \mathrm{~nm}$. All blood samples were kept in darkness during the whole procedure. The serum FITC-d concentration is positively correlated to intestinal permeability. High blood FITC-d level indicates intestinal leakage due to gut breakage caused by Eimeria spp. invasion.

At the end of the study, a 0 to 4 (no lesion to severe lesion) scale grading was used to score the coccidia lesion severity in predefined intestinal regions [18]. The upper (duodenum), middle (jejunum and ileum), and ceca sections of the intestine were scored separately. Lesion scoring was carried out on three birds per cage. 


\subsection{Sample Collection}

All the birds were euthanized by carbon dioxide asphyxiation on $\mathrm{d} 21$. Jejunal digesta was collected from five birds per cage. The samples were oven-dried and ground for oligosaccharides composition analysis. Cecal contents were collected from two birds per cage and stored at dry ice for later SCFA analysis. Jejunal tissues were sampled from two birds per cage, snap-frozen in liquid $\mathrm{N}$, and later stored at $-80^{\circ} \mathrm{C}$ before further analysis.

\subsection{Quantitative Real-Time PCR Analysis}

Quantitative real-time PCR was used to analyze gene expression related to tight junctions and intestinal nutrient transporters. Approximately $2 \mathrm{~mm} \times 2 \mathrm{~mm}$ jejunal tissue was homogenized in QIAzol lysis reagent (QIAGEN, Hilden, Germany) and total RNA was extracted following the manufacturer's instructions. Extracted RNA was converted to cDNA in a 96-well PCR system by the use of the High-Capacity cDNA Reverse Transcription Kit (Thermo Fisher Scientific, Waltham, MA, USA) after quantity measurement and dilution. Converted cDNA was diluted and the real-time PCR reaction was performed with reaction master mix iTaq Universal SYBR Green Supermix (Bio-Rad, Hercules, CA, U.S.) in a Step One Plus real-time PCR system (Thermo Fisher Scientific, Waltham, MA, U.S.). Samples were run in duplicate and the $2^{(-\Delta \Delta \mathrm{Ct})}$ method [19] was applied to analyze the results. All of the primers used in the experiments, including housekeeping and target genes, are listed in Table 3.

\subsection{Chemical Analysis}

All the diets were analyzed for chemical profiles using standard procedures. Samples were oven-dried at $100{ }^{\circ} \mathrm{C}$ for $24 \mathrm{~h}$ to determine the gravimetric difference and then dry matter was calculated (AOAC Method 934.01). Nitrogen content was measured using the combustion by nitrogen analyzer (AOAC Method 968.06). The Ankom 200 Fiber Analyzer was used to measure acid and neutral detergent fibers (Ankom Technology, Macedon, NY, USA). Minerals were measured by the Central Analytical Laboratory, University of Arkansas. Matrix-assisted laser desorption ionization mass spectrometry detection was used to analyze the oligosaccharides' composition of the jejunal by the Complex Carbohydrate Research Center, University of Georgia, as previously described [17]. Gas chromatography (GC) was used to analyze the composition of cecal SCFA by a previously described method [20]. Briefly, $1 \mathrm{~g}$ cecal content sample was diluted in $3 \mathrm{~mL}$ deionized water and centrifuged at $10,000 \times g$ for $10 \mathrm{~min}$. The supernatant was mixed well with $25 \%$ meta-phosphoric acid. After overnight freezing, the mixture was thawed and the supernatant was mixed with ethyl acetate at a ratio of 1:2. After vortexed and settled, the top layer of the mixture was transferred to a glass vial and analyzed on GC. 
Table 3. GenBank accession number, sequences of forward and reverse primers used for real-time PCR.

\begin{tabular}{|c|c|c|c|c|c|}
\hline Gene Symbol & Accession Number & Full Name & Function & Forward Primer & Reverse Primer \\
\hline $18 \mathrm{~S}$ & XR_003078042.1 & $18 \mathrm{~S}$ ribosomal RNA & Housekeeping gene & AGCCTGCGGCTTAATTTGAC & CAACTAAGAACGGCCATGCA \\
\hline Beta-actin & NM_205518.1 & Beta-actin & Housekeeping gene & CAACACAGTGCTGTCTGGTGGTA & ATCGTACTCCTGCTTGCTGATCC \\
\hline CLDN1 & NM_001013611.2 & Claudin-1 & Tight junction & TGGAGGATGACCAGGTGAAGA & CGAGCCACTCTGTTGCCATA \\
\hline PepT1 (SLC15A1) & KF366603.1 & Peptide transporter-1 & Peptide transporter & ССССTGAGGAGGATCACTGTT & CAAAAGAGCAGCAGCAACGA \\
\hline GLUT1 (SLC2A1) & NM_205209.1 & Glucose transporter-1 & Glucose transporter & CTTTGTCAACCGCTTTGG & CAGAATACAGGCCGATGAT \\
\hline GLUT2 (SLC2A2) & XM_010716927.3 & Glucose transporter-2 & Glucose transporter & TCATTGTAGCTGAGCTGTT & CGAAGACAACGAACACATAC \\
\hline SGLT1 (SLC5A1) & NM_001293240.1 & $\begin{array}{l}\text { Sodium glucose } \\
\text { transporter-1 }\end{array}$ & Glucose transporter & GCCGTGGCCAGGGCTTA & CAATAACCTGATCTGTGCACCAGT \\
\hline CAT2 (SLC7A2) & XR_005859133.1 & $\begin{array}{l}\text { Cationic amino acid } \\
\text { transporter- } 2\end{array}$ & $\begin{array}{l}\text { Cationic amino acid } \\
\text { transporter }\end{array}$ & TGCTCGCGTTCCCAAGA & GGCCCACAGTTCACCAACAG \\
\hline y+LAT1 (SLC7A7) & XM_040665181.1 & $\begin{array}{c}y+\text { L type amino acid } \\
\text { transporter- } 1\end{array}$ & $\begin{array}{l}\text { Cationic amino acid } \\
\text { transporter }\end{array}$ & CAGAAAACCTCAGAGCTCCCTTT & TGAGTACAGAGCCAGCGCAAT \\
\hline rBAT (SLC3A1) & XM_040667709.1 & $\begin{array}{l}\text { Solute carrier family } 3, \\
\text { member } 1\end{array}$ & Dimerize with $b^{o,+} A T$ & CCCGCCGTTCAACAAGAG & AATTAAATCCATCGACTCCTTTGC \\
\hline
\end{tabular}




\subsection{Statistical Analysis}

The data for Expt.1 and 2 were analyzed separately by ANOVA using the mixed model procedure of JMP Pro 14.1.0 (SAS Institute Inc., Cary, NC, USA). The two factors were the Eimeria challenge and enzymes supplementation. Main effects refer to when there are no significant interactions, whereas simple effects refer to when there are significant interactions of factors. In cases of a significant interaction effect being detected, Tukey was used to separate the significantly different means. The Kruskal-Wallis nonparametric statistical method was used to analyze intestinal lesion scores. Significance was declared at $p \leq 0.05$.

\section{Results}

\subsection{Growth Performance}

In both Expt. 1 and 2, Eimeria challenge resulted in a significant reduction $(p<0.01)$ in WG, FI, and gain-feed ratio (Tables 4 and 5). Supplemental XP increased $(p<0.05)$ FI in broilers fed LFLP diets (Expt. 2) but had no effect on growth performance of broiler fed HFAP diet (Expt. 1). In both experiments, there was no significant challenge $\times$ enzyme interaction for the growth performance responses.

Table 4. Growth performance of the broiler chickens challenged or unchallenged with mixed Eimeria spp. in response to feeding diets with high fiber and adequate protein levels with or without enzymes supplementation (Expt. 1).

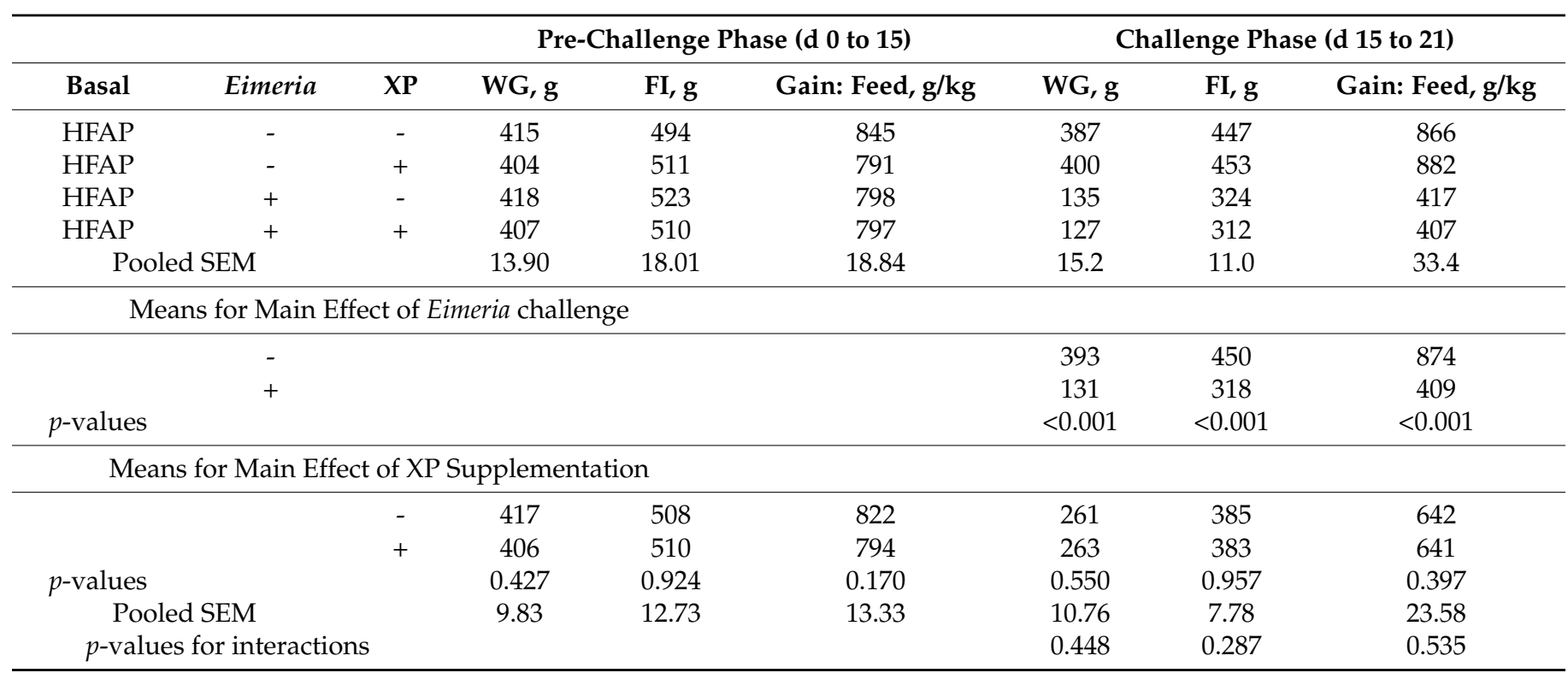

$n=6$ replicates for the simple effect; $n=12$ replicates for the main effects. HF-high fiber; AP_adequate protein; XP—xylanase plus protease supplementation; WG—weight gain, g; FI—feed intake, $\mathrm{g}$.

Table 5. Growth performance of the broiler chickens challenged or unchallenged with mixed Eimeria spp. in response to feeding diets with low fiber and low protein levels with or without enzymes supplementation (Expt. 2).

\begin{tabular}{lcccccccc}
\hline & & \multicolumn{3}{c}{ Pre-Challenge Phase (d 0 to 15) } & \multicolumn{3}{c}{ Challenge Phase (d 15 to 21) } \\
\hline Basal & Eimeria & XP & WG, g & FI, g & Gain: Feed, g/kg & WG, g & FI, g & Gain: Feed, g/kg \\
\hline LFLP & - & - & 389 & 502 & 774 & 389 & 502 & 774 \\
LFLP & - & + & 390 & 507 & 769 & 384 & 454 & 845 \\
LFLP & + & - & 368 & 486 & 755 & 145 & 313 & 462 \\
LFLP & + & + & 423 & 557 & 759 & 145 & 324 & 447 \\
\multicolumn{2}{l}{ Pooled SEM } & & 40.5 & 54.6 & 43.95 & 28.91 & 21.86 & 58.45 \\
\hline
\end{tabular}


Table 5. Cont.

\begin{tabular}{|c|c|c|c|c|c|c|c|c|}
\hline \multirow[b]{2}{*}{ Basal } & \multirow[b]{2}{*}{ Eimeria } & \multirow[b]{2}{*}{$\mathbf{X P}$} & \multicolumn{3}{|c|}{ Pre-Challenge Phase (d 0 to 15 ) } & \multicolumn{3}{|c|}{ Challenge Phase (d 15 to 21) } \\
\hline & & & WG, $\mathrm{g}$ & FI, $\mathrm{g}$ & Gain: Feed, g/kg & WG, $\mathrm{g}$ & FI, $\mathrm{g}$ & Gain: Feed, g/kg \\
\hline \multicolumn{9}{|c|}{ Means for Main Effect of Eimeria Challenge } \\
\hline & - & & & & & 372 & 438 & 848 \\
\hline & + & & & & & 145 & 318 & 455 \\
\hline$p$-values & & & & & & $<0.001$ & $<0.001$ & $<0.001$ \\
\hline \multicolumn{9}{|c|}{ Means for Main Effect of XP Supplementation } \\
\hline & & - & 379 & 494 & 764 & 252 & 367 & 657 \\
\hline & & + & 406 & 532 & 749 & 264 & 389 & 646 \\
\hline$p$-values & & & 0.113 & 0.114 & 0.460 & 0.391 & 0.042 & 0.708 \\
\hline Po & EM & & 11.68 & 15.77 & 12.69 & 8.35 & 6.31 & 16.87 \\
\hline$p$-val & $r$ interacti & & & & & 0.370 & 0.303 & 0.868 \\
\hline
\end{tabular}

$n=6$ replicates for the simple effect; $n=12$ replicates for the main effects. LF-high fiber; LP—low protein; XP—xylanase plus protease supplementation; WG—weight gain, g; FI—feed intake, g.

\subsection{Intestinal Permeability and Lesion Scores}

Figures 1 and 2 show the gastrointestinal permeability response on day 19 (5 DPI). Enzyme supplementation had no effect on intestinal permeability compared with the control group (unchallenged treatment without enzymes) in both experiments. However, birds challenged with mixed Eimeria species showed higher $(p<0.01)$ serum FITC-d levels, indicating intestinal leakage due to gut breakage caused by Eimeria spp. invasion. The results of intestinal lesion scores are presented in Figures 3 and 4, compared to the control group (unchallenged treatment without enzyme). Eimeria challenge resulted in higher $(p<0.01)$ lesion scores in the upper intestine, middle intestine, and ceca which were invaded by E. acervulina, E. maxima, and E. tenella, respectively, regardless of the type of basal diets. No significant effect on lesion score was observed for XP supplementation.

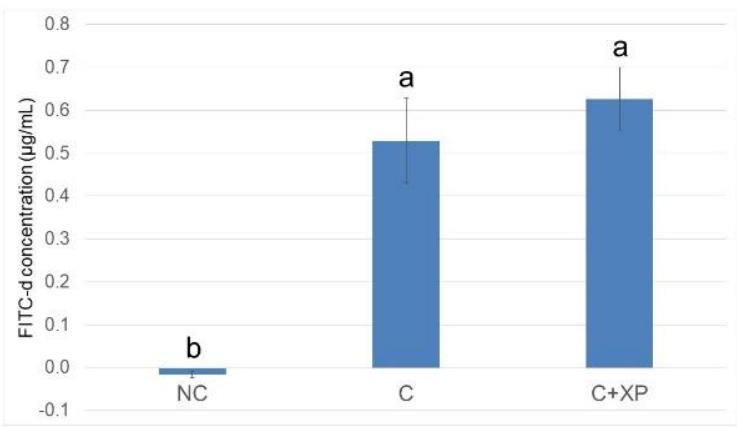

Figure 1. Fluorescein isothiocyanate dextran concentration (FITC-d, $\mu \mathrm{g} / \mathrm{mL}$ ) in serum of broiler chickens in response to feeding HFAP diet with or without enzyme supplementation (Expt. 1). Treatments with different letters are significantly different $(p<0.05) . N=6$. NC, unchallenged (no enzyme) treatment; $C$, challenged (no enzyme) treatment; $C+X \mathrm{P}$, challenged and supplemented with xylanase and protease treatment. The error bars represent the SEM values. 


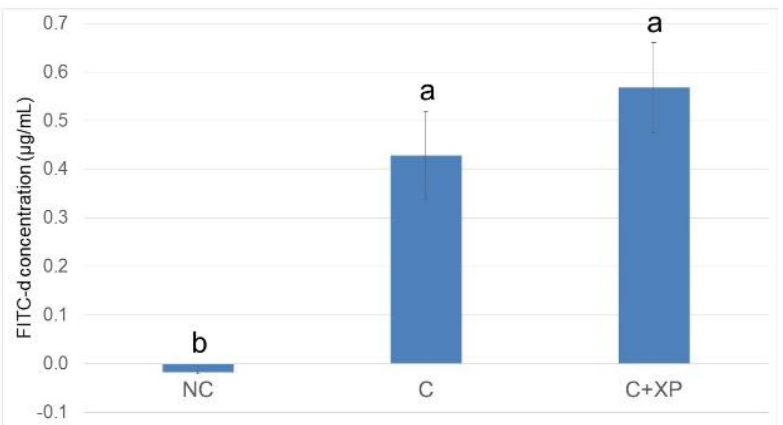

Figure 2. Fluorescein isothiocyanate dextran concentration (FITC-d, $\mu \mathrm{g} / \mathrm{mL}$ ) in serum of broiler chickens in response to feeding LFLP diet with or without enzyme supplementation (Expt. 2). Treatments with different letters are significantly different $(p<0.05) . N=6$. NC, unchallenged (no enzyme) treatment; $C$, challenged (no enzyme) treatment; $C+X \mathrm{P}$, challenged and supplemented with xylanase and protease treatment. The error bars represent the SEM values.



(a)

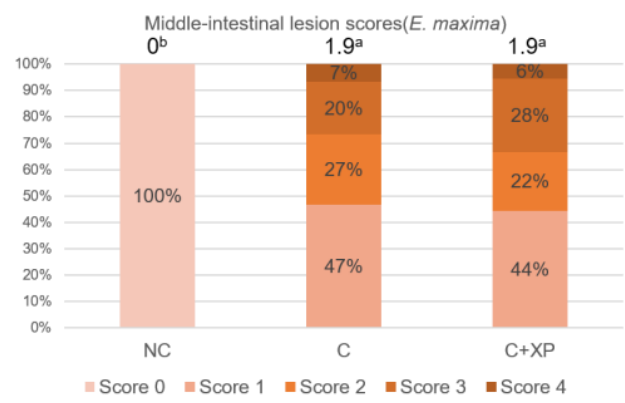

(b)

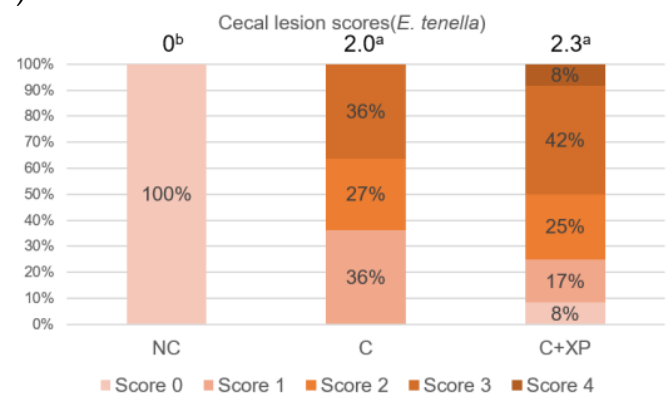

(c)

Figure 3. Lesion scores in the upper intestine, middle intestine, and ceca of broiler chicken in response to feeding HFAP diet with or without enzyme supplementation (Expt. 1; 6 days post-infection). Average scores for each treatment are presented at the top of the bar. Treatments with different letters are significantly different ( $p<0.05$ ): (a) Upper-intestine; (b) middle-intestine; (c) ceca. $N=6$. NC, unchallenged-no enzyme treatment; $C$, challenged-no enzyme treatment; $C+X P$, challenged and supplemented with xylanase and protease treatment. 


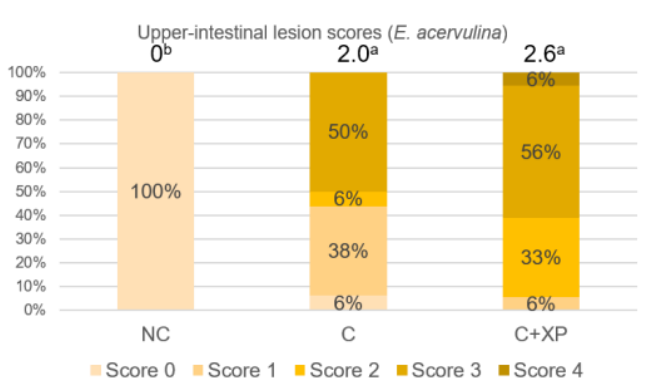

(a)

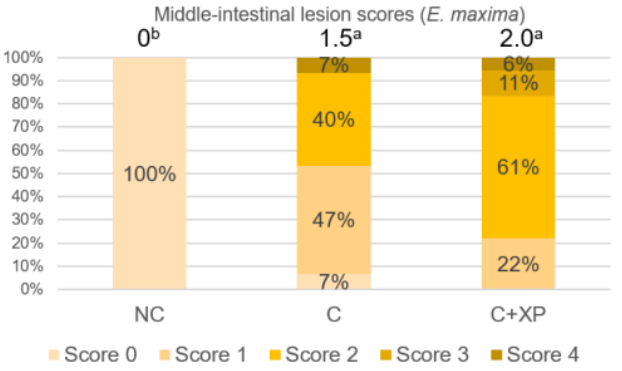

(b)

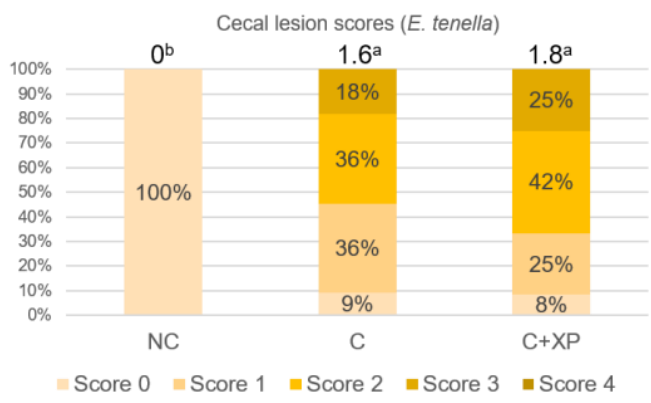

(c)

Figure 4. Lesion scores in the upper intestine, middle intestine, and ceca of broiler chicken in response to feeding LFLP diet with or without enzyme supplementation (Expt. 2; 6 days post-infection). Average scores for each treatment are presented at the top of the bar. Treatments with different letters are significantly different $(p<0.05)$ : (a) Upper-intestine; (b) middle-intestine; (c) ceca. $N=6 . \mathrm{NC}$, unchallenged-no enzyme treatment; $\mathrm{C}$, challenged-no enzyme treatment; $\mathrm{C}+\mathrm{XP}$, challenged and supplemented with xylanase and protease treatment.

\subsection{Gene Expression of Nutrients Transporters and Tight Junction Proteins}

In Expt. 1 , Eimeria challenge upregulated $(p<0.01)$ the expression of CLDN1, whereas enzyme supplementation downregulated $(p<0.01)$ the expression of the gene. Moreover, there was a significant $(p<0.01)$ enzyme $\times$ Eimeria challenge interaction for the expression of glucose transporters GLUT2 and GLUT5 (Table 6). In unchallenged groups, enzyme supplementation reduced $(p<0.05)$ the expression, while in Eimeria-challenged groups, the expression levels were unaffected. The highest and lowest GLUT2 and GLUT5 expressions were observed in unchallenged (without enzyme) and unchallenged (with enzyme) treatments, respectively. Downregulation $(p<0.05)$ of glucose transporter SGLT1 was observed in enzyme-supplemented diets in Expt. 1. In addition, the Eimeria challenge downregulated $(p<0.05)$ the expression of CAT2 and $\mathrm{y}+\mathrm{LAT} 1$. Downregulation $(p<0.05)$ of amino acid transporter rBAT was observed in enzyme-supplemented diets in Expt. 1. The expression of JAM2 and PepT1 were not affected by the treatments in both experiments. In Expt. 2, there was no interaction between enzyme supplementation and Eimeria challenge on gene expression. In addition, Eimeria significantly upregulated $(p<0.01)$ tight junction protein CLDN1 and downregulated $(p<0.01)$ the expression of cationic amino acid transporters CAT2 and $y+$ LAT1 whereas enzyme supplementation had no significant effect on the gene expression (Table 7). 
Table 6. Effects of mixed Eimeria spp. infection and exogenous enzymes on gene expression of tight junctions and nutrient transporters in the jejunum of broiler chickens on 6 days post-infection (HFAP; Expt. 1).

\begin{tabular}{|c|c|c|c|c|c|c|c|c|c|}
\hline Basal & Eimeria & $\mathbf{X P}$ & CLDN1 & GLUT2 & GLUT5 & SGLT1 & CAT2 & $y+L A T 1$ & rBAT \\
\hline HFAP & - & - & 1.016 & $0.762^{\mathrm{a}}$ & $1.108^{\mathrm{a}}$ & 1.146 & 1.050 & 1.084 & 1.132 \\
\hline HFAP & - & + & 0.411 & $0.072^{b}$ & $0.136^{\mathrm{b}}$ & 0.237 & 0.846 & 0.975 & 0.538 \\
\hline HFAP & + & - & 1.796 & $0.200^{\mathrm{b}}$ & $0.305^{\mathrm{b}}$ & 1.385 & 0.512 & 0.478 & 0.758 \\
\hline HFAP & + & + & 1.070 & $0.183^{b}$ & $0.248^{b}$ & 0.892 & 0.503 & 0.394 & 0.395 \\
\hline Poole & EM & & 0.172 & 0.067 & 0.120 & 0.477 & 0.187 & 0.150 & 0.277 \\
\hline \multicolumn{10}{|c|}{ Means for Main Effect of Eimeria Challenge } \\
\hline & - & & 0.714 & 0.417 & 0.622 & 0.692 & 0.948 & 1.029 & 0.835 \\
\hline & + & & 1.433 & 0.191 & 0.277 & 1.139 & 0.507 & 0.436 & 0.577 \\
\hline$p$-values & & & 0.002 & 0.010 & 0.014 & 0.155 & 0.039 & 0.002 & 0.171 \\
\hline \multicolumn{10}{|c|}{ Means for Main Effect of XP Supplementation } \\
\hline & & - & 1.406 & 0.481 & 0.706 & 1.266 & 0.781 & 0.781 & 0.945 \\
\hline & & + & 0.740 & 0.127 & 0.192 & 0.564 & 0.674 & 0.684 & 0.467 \\
\hline$p$-values & & & 0.004 & $<0.001$ & 0.001 & 0.032 & 0.597 & 0.560 & 0.017 \\
\hline \multicolumn{3}{|c|}{ Pooled SEM } & 0.122 & 0.048 & 0.085 & 0.337 & 0.132 & 0.106 & 0.196 \\
\hline \multicolumn{3}{|c|}{$p$-values for interactions } & 0.761 & 0.001 & 0.002 & 0.498 & 0.630 & 0.535 & 0.532 \\
\hline
\end{tabular}

$n=6$ replicates for the simple effect; $n=12$ replicates for the main effects. HF-high fiber; AP-adequate protein; $\mathrm{XP}-\mathrm{xylanase}$ plus protease supplementation. Means with different superscripts are significantly different $(p<0.05)$.

Table 7. Effects of mixed Eimeria spp. infection and exogenous enzymes on gene expression of tight junctions and nutrient transporters of jejunum in broiler chickens on 6 days post infection (LFLP; Expt. 2).

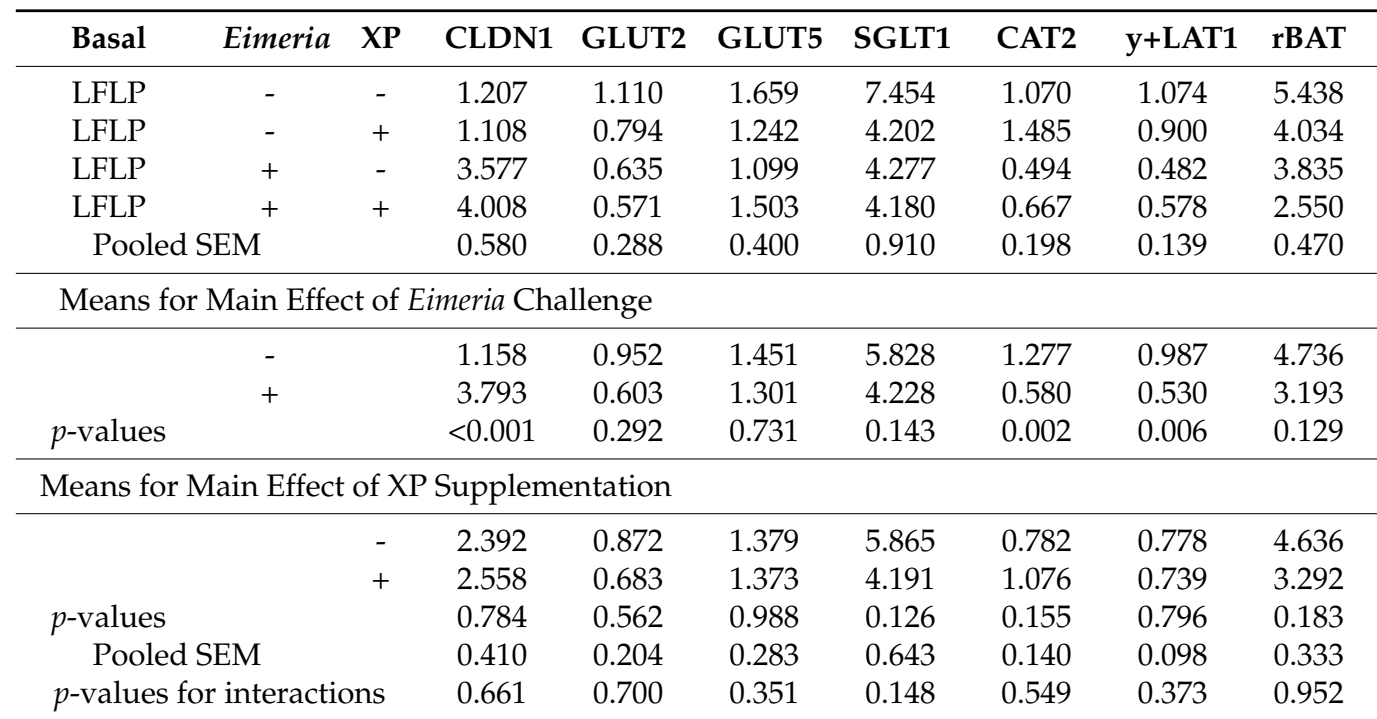

$n=6$ replicates for the simple effect; $n=12$ replicates for the main effects. LF-high fiber; LP-low protein; $\mathrm{XP}-\mathrm{xylanase}$ plus protease supplementation.

\subsection{Jejunal Oligosaccharides and Cecal Volatile Fatty Acids Profile}

No significant main or interaction effects were observed on the profile of jejunal oligosaccharides in birds receiving the HFAP diet in Expt. 1 (Table 8). The profile of jejunal oligosaccharides in Expt. 2 (Table 9) indicates that birds challenged with mixed Eimeria spp. tended to have lower jejunal concentration of (Hex)3 $(p=0.062)$ and $(\mathrm{Hex}) 5(p=0.059)$ but significantly lower (Hex) $4(p<0.05)$, when fed LFLP diets. No significant enzyme effect nor interactions were observed.

In both Expt. 1 and Expt. 2 (Table 10 and Table 11, respectively), there were significantly lower $(p<0.05)$ concentrations of SCFA acetate, butyrate, and total SCFA but higher 
$(p<0.05)$ concentrations of BCFA isobutyrate, and isovalerate in birds challenged with Eimeria spp. In birds receiving HFAP diets (Expt. 1), there was significant Eimeria $\times$ enzyme interaction for isobutyrate, isovalerate, and valerate (Table 10). The concentrations of BCFA were much greater $(p<0.05)$ in challenged birds than in unchallenged birds. Enzyme supplementation mollified Eimeria-induced increase in cecal BCFA isobutyrate and isovalerate contents. Lower $(p<0.05)$ cecal valerate was observed in birds fed without enzymes in challenged compared to unchallenged birds. However, when enzymes were supplemented, challenged birds had a higher $(p<0.05)$ cecal valerate value compared to unchallenged birds. No significant main enzymatic effects were found. For broiler chickens in Expt. 2, there was significant Eimeria $\times$ enzymes interaction $(p<0.05)$ for ceca content of acetate, butyrate, and total SCFA (Table 11). The concentrations of acetate, isobutyrate, and total VFA were highest $(p<0.05)$ in unchallenged-no enzyme treatments, but similar among the rest of the treatments.

Table 8. Oligosaccharide profile $(\mu \mathrm{g} / \mathrm{mg})$ in jejunal digesta of broiler chickens challenged or unchallenged with mixed Eimeria spp. in response to feeding diets with high fiber and adequate protein levels with or without enzyme supplementation (Expt. 1).

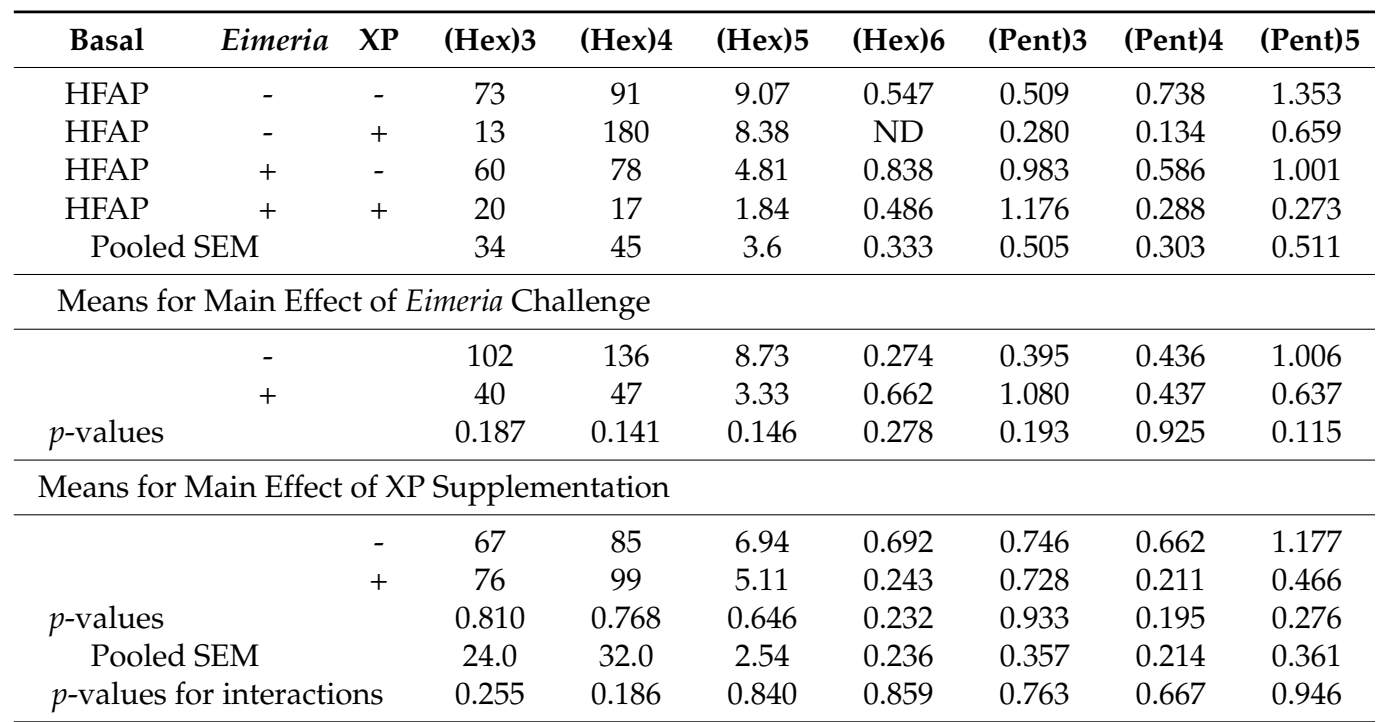

$n=6$ replicates for diet effect; $n=12$ replicates for the main effects. HF-high fiber; AP—adequate protein; $\mathrm{XP}$-xylanase plus protease supplementation; Hex—hexose; Pent—pentose; ND—not detected.

Table 9. Oligosaccharide profile ( $\mu \mathrm{g} / \mathrm{mg})$ in jejunal digesta of broiler chickens challenged or unchallenged with mixed Eimeria spp. in response to feeding diets with low fiber and protein levels with or without enzyme supplementation (Expt. 2).

\begin{tabular}{|c|c|c|c|c|c|c|c|c|c|}
\hline Basal & Eimeria & $\mathbf{X P}$ & (Hex)3 & (Hex)4 & (Hex)5 & (Hex)6 & (Pent)3 & (Pent)4 & (Pent)5 \\
\hline LFLP & - & - & 140 & 150 & 7.39 & 0.121 & 5.791 & 0.699 & 0.929 \\
\hline LFLP & - & + & 134 & 154 & 6.27 & ND & 3.181 & ND & 1.158 \\
\hline LFLP & + & - & 49 & 22 & 2.85 & ND & 2.109 & 0.333 & 0.350 \\
\hline LFLP & + & + & 19 & 12 & 0.70 & ND & 2.257 & 0.501 & 0.448 \\
\hline \multicolumn{2}{|c|}{ Pooled SEM } & & 49 & 51 & 2.84 & 0.064 & 2.258 & 0.348 & 0.633 \\
\hline \multicolumn{10}{|c|}{ Means for Main Effect of Eimeria Challenge } \\
\hline \multicolumn{3}{|c|}{ 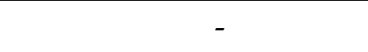 } & 137 & 152 & 6.83 & 0.060 & 4.486 & 0.349 & 1.044 \\
\hline & \multicolumn{2}{|l|}{+} & 34 & 17 & 1.78 & ND & 2.183 & 0.417 & 0.399 \\
\hline$p$-values & & & 0.062 & 0.034 & 0.059 & 0.398 & 0.581 & 0.862 & 0.834 \\
\hline
\end{tabular}


Table 9. Cont.

\begin{tabular}{ccccccccc}
\hline Basal Eimeria & XP & $\mathbf{( H e x ) 3}$ & $\mathbf{( H e x ) 4}$ & $\mathbf{( H e x ) 5}$ & $\mathbf{( H e x ) 6}$ & $\mathbf{( P e n t ) 3}$ & $\mathbf{( P e n t ) 4}$ & (Pent)5 \\
\hline $\begin{array}{c}\text { Means for Main Effect of XP } \\
\text { Supplementation }\end{array}$ & & & & & & \\
\hline & - & 95 & 86 & 5.12 & 0.060 & 3.950 & 0.516 & 0.639 \\
& + & 76 & 83 & 3.48 & ND & 2.719 & 0.250 & 0.803 \\
$p$-values & & 0.765 & 0.974 & 0.676 & 0.375 & 0.644 & 0.490 & 0.103 \\
Pooled SEM & 35 & 36 & 2.01 & 0.045 & 1.596 & 0.246 & 0.447 \\
$p$-values for interactions & 0.804 & 0.894 & 0.840 & 0.372 & 0.595 & 0.274 & 0.933 \\
\hline
\end{tabular}

$n=6$ replicates for diet effect; $n=12$ replicates for the main effects. LF-low fiber; LP-low protein; XP—xylanase plus protease supplementation; Hex-hexose; Pent-pentose; ND—not detected.

Table 10. Short-chain fatty acid profile $(\mathrm{mM})$ in cecal content for the broiler chickens challenged or unchallenged with mixed Eimeria spp. in response to feeding diets with high fiber and adequate protein levels with or without enzyme supplementation (Expt. 1).

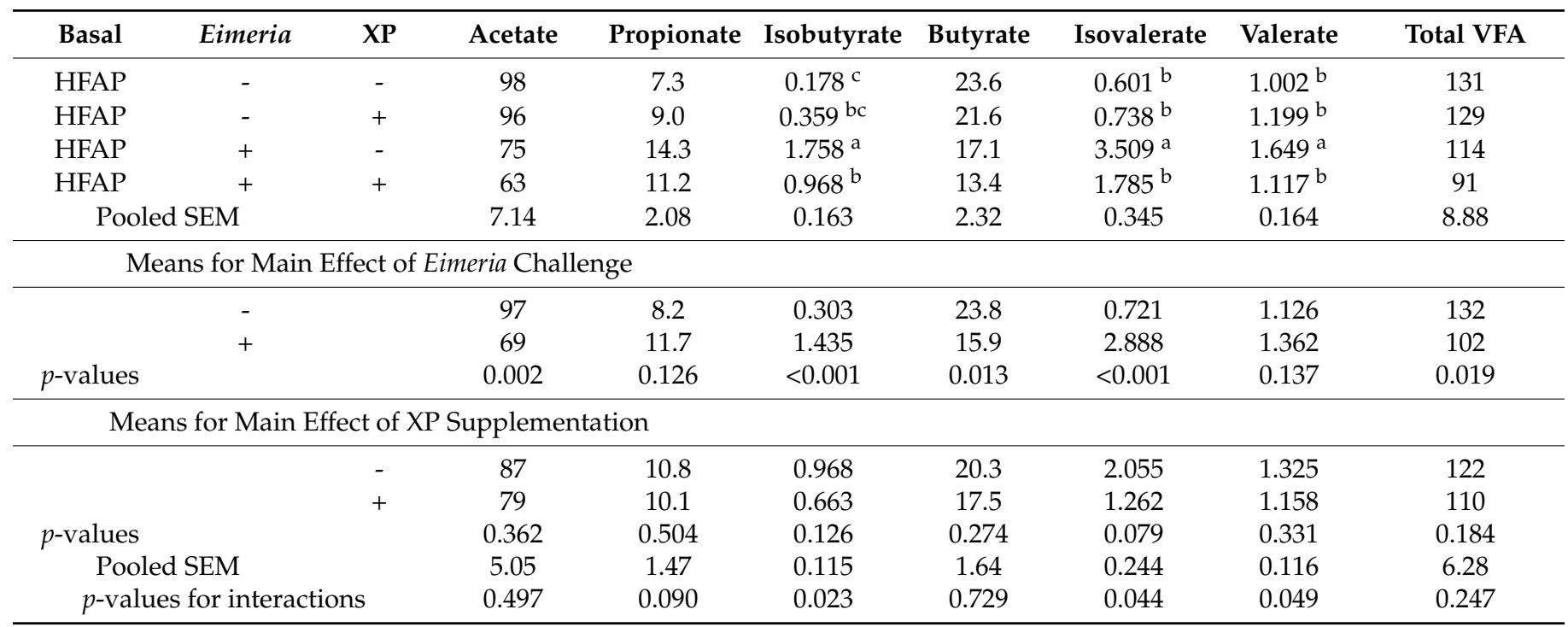

$n=6$ replicates for diet effect; $n=12$ replicates for main effects. HF-high fiber; AP-adequate protein; XP-xylanase plus protease supplementation. Means with different superscripts are significantly different $(p<0.05)$.

Table 11. Short-chain fatty acid profile $(\mathrm{mM})$ in cecal content for the broiler chickens challenged or unchallenged with mixed Eimeria spp. in response to feeding diets with low fiber and protein levels with or without enzyme supplementation (Expt. 2).

\begin{tabular}{|c|c|c|c|c|c|c|c|c|c|}
\hline Basal & Eimeria & $\mathbf{X P}$ & Acetate & Propionate & Isobutyrate & Butyrate & Isovalerate & Valerate & Total VFA \\
\hline LFLP & - & - & $116^{\mathrm{a}}$ & 9.1 & 0.279 & $29.5^{a}$ & 0.664 & 1.373 & $157^{\mathrm{a}}$ \\
\hline LFLP & - & + & $87^{b}$ & 9.0 & 0.409 & $21.3^{\mathrm{ab}}$ & 0.798 & 1.106 & $120^{a b}$ \\
\hline LFLP & + & - & $68^{b}$ & 11.4 & 1.170 & $15.1^{\mathrm{b}}$ & 2.313 & 1.251 & $99^{b}$ \\
\hline LFLP & + & + & $71^{b}$ & 13.0 & 1.628 & $16.5^{b}$ & 3.674 & 1.645 & $108^{b}$ \\
\hline \multicolumn{2}{|c|}{ Pooled SEM } & & 6.9 & 1.98 & 0.189 & 2.71 & 0.409 & 0.183 & 9.16 \\
\hline \multicolumn{10}{|c|}{ Means for Main Effect of Eimeria Challenge } \\
\hline \multicolumn{3}{|c|}{-} & 103 & 8.8 & 0.264 & 25.8 & 0.621 & 1.220 & 140 \\
\hline & \multirow{2}{*}{\multicolumn{2}{|c|}{+}} & 72 & 14.2 & 1.561 & 16.5 & 3.371 & 1.591 & 109 \\
\hline$p$-values & & & 0.002 & 0.300 & 0.002 & 0.046 & 0.002 & 0.415 & 0.018 \\
\hline
\end{tabular}


Table 11. Cont.

\begin{tabular}{cccccccccc}
\hline Basal & Eimeria & XP & Acetate & Propionate & Isobutyrate & Butyrate & Isovalerate & Valerate & Total VFA \\
\hline Means for Main Effect of XP Supplementation & & & & & & & \\
\hline & - & 92 & 10.2 & 0.724 & 22.3 & 1.488 & 1.312 & 128 \\
& + & 79 & 11.0 & 1.018 & 18.9 & 2.236 & 1.376 & 114 \\
$p$-values & & 0.113 & 0.878 & 0.188 & 0.196 & 0.124 & 0.755 & 0.118 \\
Pooled SEM & 4.75 & 1.33 & 0.150 & 2.156 & 0.329 & 0.142 & 6.67 \\
$p$-values for interactions & 0.046 & 0.422 & 0.395 & 0.045 & 0.150 & 0.088 & 0.015 \\
\hline
\end{tabular}

$n=6$ replicates for diet effect; $n=12$ replicates for main effects. LF-low fiber; LP-low protein; XP-xylanase plus protease supplementation. Means with different superscripts are significantly different $(p<0.05)$.

\section{Discussion}

The objective of the two experiments reported herein was to investigate the potential and mechanisms of exogenous enzymes action on mitigating the negative effects of Eimeria challenge on growth performance, gene expression of tight junctions and nutrient transporters, and cecal fermentation pattern. Eimeria-induced reduction in broiler growth performance is positively correlated with infective dose [21,22]. Bodyweight gain of birds at 1 to 6 DPI (day 14 to day 20) can be linearly reduced from $27 \%$ to $49 \%$ when challenged by increasing oocysts doses of mixed Eimeria spp. (6250 E. maxima; 6250 E.tenella; 31,250 E. acervuline to 50,000 E. maxima; 50,000 E. tenella; 250,000 E. acervulina) [21]. A medium-low dose of Eimeria was used in the current study in order to develop a mild infection resulting in a $63 \%$ reduction in body weight gain at 6 DPI, which was more severe than expected but similar to what others have reported $[23,24]$. There are species differences in the extent to which Eimeria impacts growth performance. The less pathogenic species such as $E$. praecox and E. mitis, which do not cause lesions, generally have less influence on growth performance whereas E. maxima, which mainly invades jejunum and ileum, showed a more serious impairment on feed conversion ratio (FCR) [1,25]. Exogenous enzymes do not have anticoccidial activities. However, dietary inclusion of such enzymes may reduce the negative effect of coccidia infection via the independent effect of such enzymes on promoting growth performance, nutrient utilization, the integrity of intestinal epithelial cells, or bacterial balance. For example, enzyme complexes including xylanase or protease have been shown to significantly decrease FCR in broiler chickens challenged with coccidia $[14,26,27]$. In Expt. 2 of the current study, enzyme supplementation increased feed intake without any effect on WG or the gain-feed ratio. The enzyme's effect during coccidia challenge is not universally observed. Enzyme supplementation had no significant mitigation effect on the impairment of the growth performance associated with coccidiosis in Parker et al. [28] or in Expt. 1 of the current study. Dietary and other factors may play a role in differences in response observed from different studies.

Eimeria challenge increases the permeability of the intestinal epithelium, and the extent of the damage can be assessed using fluorescein isothiocyanate-dextran (FITCd). Higher levels of FITC-d in serum indicate greater FITC-d leakage from the intestine, revealing the severity of impairment of tight junction barriers [29]. Upon entering the host intestine, sporulated oocysts begin several cycles of asexual multiplication before sexual multiplication. During the asexual multiplication stages, a mass of merozoites is produced and penetrates the epithelial cells of the host, resulting in severe intestinal impairment and permeability defects [3]. In the current study, the levels of FITC-d detected in bird serum were greater in challenged birds compared with non-challenged birds. However, enzyme supplementation had no effect on gut leakage. The observation was likely because enzymes cannot directly target Eimeria oocyst nor reduce its multiplication, which is the primary cause of cell destruction and gut leakage. For the same reason, there was no lesion score reduction observed in enzyme-supplemented treatments.

On the other hand, observation in the current experiments on the expression of tight junction proteins indicates that the enzymes supplementation promoted intestinal integrity. Tight junctions are multi-functional protein complexes principally consisting of 
three families of transmembrane proteins: claudins, occludins, and junctional adhesion molecules. These complexes act as guards to seal the paracellular space between adjacent epithelial cells, regulating nutrient absorption and restricting pathogen entry. Claudin family proteins constitute the tight junction structural framework and each protein plays a specific function [30]. In the current study, in response to the mixed Eimeria challenge, the expression of claudin-1 at 6 DPI was significantly increased. The same change of claudin-1 was reported in previous coccidia studies [21,31]. The key inflammatory cytokine $\mathrm{TNF} \alpha$ led to the increase in claudin-1 in IEC-18 cells, and increased expression of claudin-1 was observed in ulcerative colitis. It is speculated that the increased claudin-1 is related to inflammatory bowel disease [32-34]. When attacked by inflammatory pathogens, the intestinal paracellular structure, as well as osmotic balance, are damaged, requiring a mass replacement of barrier-forming proteins including claudin- 1 . This intensive replacement is clinically observed as diarrhea. This replacement can not only renew intestinal barriers but also protectively exclude invasive pathogens [34]. Eimeria spp. multiplies by invading and breaking down intestinal cells intercellularly and intracellularly. All of these Eimeriainduced activities stimulate the replacement of tight junctions, consequently increasing the expression of claudin-1, which was also observed in the current study. The data in the current study demonstrated the combined effect of xylanase and protease on decreasing the claudin-1 expression. It can be reasoned that the enzymes helped to partly alleviate Eimeria-induced intestinal barrier impairment and thus helped reduce the metabolic costs associated with the disease challenge. Similar findings were reported in animals receiving xylanase supplemented diet when challenged with Clostridium perfringens $[35,36]$.

Eimeria infection causes the downregulation of nutrient transporters, which consequently contributes to possible depressed nutrient utilization and ultimately diminished growth performance [37]. In the current study, Eimeria infection significantly downregulated the expression of sugar transporters GLUT2 and GLUT5 in broilers fed HFAP diets (Expt. 1), although the decrease was rather nominal for birds receiving LFLP diets in Expt. 2. GLUT5, located on the apical side, is a facilitated-diffusion fructose transporter that facilitates the uptake of fructose into enterocytes. GLUT2, located at the basolateral side, takes over the sugar absorption transport once inside the cell and mediates the passive transport of glucose, fructose, and galactose out of enterocytes into the bloodstream $[38,39]$. Others have similarly observed the downregulation of intestinal GLUT2, GLUT5, and SGLT1 in Eimeria- and Campylobacter jejuni-challenged birds [7,22,37,40]. In the current study, amino acid transporters CAT2 and y+LAT1 were also downregulated in Eimeriachallenged groups regardless of the dietary fiber and protein levels. This observation is consistent with previous observations that E. maxima caused ileal and E. tenella caused jejunal CAT2/y+LAT1 downregulation [37]. CAT2 and y+LAT1 are basolateral amino acid transporters mediating the transport of cationic and neutral amino acids [41]. As important L-arginine transporters, the depression of CAT2 and y+LAT1 may contribute to the reported sharp drop of plasma arginine in E. acervulina challenged chickens [42].

The downregulation of nutrient transporter proteins caused by Eimeria challenge affects a wide range of sugar and amino acid transporter proteins such as GLUT2, GLUT5, SGLT1, PepT1, b0AT, b0+AT, EAAT3, rBAT, y+LAT2 [6,7,37,43]. The causes for the downregulation effect are not clear, but it is speculated that this response is a cell-mediated protective reaction in response to pathogenic invasion. By downregulating nutrient transporters in epithelial cells, a depleted nutritional environment is created to limit the development of parasites. In addition, the malnourished cells may trigger apoptosis and consequent epithelial renewal [6,37]. The interaction between Eimeria challenge and enzyme supplementation in HFAP diets (Expt. 1) showed that compared to the non-challenged treatments, enzyme supplementation upregulated the expression of GLUT2 and GLUT5 to possibly compensate for nutrient utilization deficit. The xylanase-mediated nutrient transporter upregulation was reported in broiler chickens challenged with Clostridium perfringens [35,44]. These observations suggest the potential of exogenous enzymes to alleviate some negative effects of Eimeria challenge in broiler chickens. 
Exogenous enzymes or dietary fiber have been shown to influence the content and profile of oligosaccharides in the digestive tract $[15,17,45,46]$. Some of these oligosaccharides could serve prebiotic functions in birds. In a study by Lin and Olukosi [17], broiler chickens receiving diets with higher fiber content had a greater content of jejunal pentoseoligosaccharides as well as cecal SCFA. In the current study, the concentration of jejunal hexose-oligosaccharides was reduced in the challenged birds receiving LFLP diets (Expt. 2 ), which is likely due to the depressed feed intake in challenged birds. On the other hand, no significant difference was observed in the jejunal oligosaccharides content in the different HFAP treatments in Expt. 1. Interestingly, the Eimeria challenge increased the cecal concentration of BCFA which exclusively originates from protein fermentation, but decreased the concentration of acetate and butyrate which mainly originate from carbohydrates fermentation, regardless of the types of diet profile in the two experiments. The production of BCFA is considered a marker for estimating cecal protein fermentation [47], thus it can be speculated that Eimeria promoted cecal protein fermentation but inhibited the fermentation of carbohydrates. This is possibly due to a change in the proportion of protein and carbohydrates reaching the hindgut for fermentation or a shift in the microbial population inhabiting the hindgut of challenged, compared with non-challenged birds.

It is widely acknowledged that hindgut fermentation of carbohydrates is generally more beneficial than protein fermentation [48]. For example, butyrate resulting largely from carbohydrate fermentation is regarded as an energy source for enterocytes. Butyrate also plays a role in reducing inflammation and oxidative stress and in enhancing the colonic defense barrier. The supplementation of butyrate was reported to control coccidiosis [49]. The greater ceca BCFA content observed in Eimeria-challenged chickens may be explained by the observed downregulation in amino acid transporters. This may lead to impaired amino acids absorption in the small intestine of the host, and consequently leading to disproportionally large amounts of protein in the hindgut. Secondly, large amounts of epithelial cell debris produced by coccidiosis-induced intestinal damage ultimately flow to the ceca as potentially fermentable protein substrates. In addition, an Eimeria-induced cecal microflora shift has been indicated in previous studies [49], leading to an increase in Firmicutes (mucins and amino acids fermentation) and Proteobacteria (amino acids fermentation) and a decrease in Bacteroidetes (carbohydrates fermentation) [50-52]. Therefore, protein fermentation is promoted at the expense of carbohydrates fermentation. Instructively though, in the current study, enzyme supplementation mitigated the Eimeria-induced enhancement of cecal BCFA in HFAP diets (Expt. 1). These observations demonstrated a potential positive effect of enzyme supplementation in alleviating the shift in microbial fermentation patterns caused by Eimeria challenge.

\section{Conclusions}

In conclusion, Eimeria challenge triggered changes to the expression of claudin 1 and nutrient transporters irrespective of the diet types. In addition, Eimeria infection resulted in the promotion of cecal protein fermentation and inhibited carbohydrates fermentation. Exogenous enzymes showed the potential of alleviating Eimeria-induced intestinal gene expression changes and mitigating the unfavorable cecal fermentation pattern, and thus demonstrated that enzyme supplementation may benefit beyond nutrient improvement.

Author Contributions: Conceptualization, O.A.O. and Y.L.; methodology, O.A.O. and Y.L.; software, Y.L.; validation, O.A.O.; formal analysis, Y.L.; investigation, O.A.O. and Y.L.; resources, O.A.O.; data curation, O.A.O.; writing-original draft preparation, Y.L.; writing-review and editing, O.A.O.; supervision, O.A.O.; project administration, O.A.O.; funding acquisition, O.A.O. All authors have read and agreed to the published version of the manuscript.

Funding: This research was funded by the United States Department of Agriculture (USDA) National Institute of Food and Agriculture, grant number 1021533. The work was also supported in part by a cooperative agreement 58-6040-8-034 from the USDA-Agricultural Research Service; and by the U.S. Department of Energy, Office of Science, Basic Energy Sciences, under Award DE-SC0015662 
to DOE-Center for Plant and Microbial Complex Carbohydrates at the Complex Carbohydrate Research Center, USA.

Institutional Review Board Statement: The experiments were conducted at the University of Georgia Poultry Research Center. All the animal experiment procedures used in this study were approved by the Institutional Animal Care and Use Committee of the University of Georgia, Athens, GA. The animal ethics approval number is A2018-08-026.

Acknowledgments: The authors acknowledge the assistance of Lindsey Rackett, Trevor Ard, Mohammad Pilevar, Shravani Veluri and Adeleye Mathew Ajao for care of animals and chemical analysis. The authors acknowledge the assistance of Krishan Mistry for writing proof.

Conflicts of Interest: The authors declare no conflict of interest.

\section{References}

1. Allen, P.C.; Fetterer, R.H. Recent advances in biology and immunobiology of Eimeria species and in diagnosis and control of infection with these coccidian parasites of poultry. Clin. Microbiol. Rev. 2002, 15, 58-65. [CrossRef]

2. Brandsch, M. Drug transport via the intestinal peptide transporter PepT1. Curr. Opin. Pharmacol. 2013, 13, 881-887. [CrossRef]

3. Conway, D.P.; McKenzie, M.E. Poultry Coccidiosis: Diagnostic and Testing Procedures, 3rd ed.; John Wiley \& Sons: New York, NY, USA, 2008; ISBN 9780813822020.

4. Dalloul, R.A.; Lillehoj, H.S. Poultry coccidiosis: Recent advancements in control measures and vaccine development. Exp. Rev. Vaccines 2006, 5, 143-163. [CrossRef]

5. Blake, D.P.; Knox, J.; Dehaeck, B.; Huntington, B.; Rathinam, T.; Ravipati, V.; Ayoade, S.; Gilbert, W.; Adebambo, A.O.; Jatau, I.D.; et al. Re-calculating the cost of coccidiosis in chickens. Vet. Res. 2020, 51, 115. [CrossRef] [PubMed]

6. Paris, N.E.; Wong, E.A. Expression of digestive enzymes and nutrient transporters in the intestine of Eimeria maxima-infected chickens. Poult. Sci. 2013, 92, 1331-1335. [CrossRef] [PubMed]

7. Su, S.; Miska, K.B.; Fetterer, R.H.; Jenkins, M.C.; Wong, E.A. Expression of digestive enzymes and nutrient transporters in Eimeria acervulina-challenged layers and broilers. Poult. Sci. 2014, 93, 1217-1226. [CrossRef] [PubMed]

8. Chen, H.L.; Zhao, X.Y.; Zhao, G.X.; Huang, H.B.; Li, H.R.; Shi, C.W.; Yang, W.T.; Jiang, Y.L.; Wang, J.Z.; Ye, L.P.; et al. Dissection of the cecal microbial community in chickens after Eimeria tenella infection. Parasites Vectors 2020, 13, 56. [CrossRef] [PubMed]

9. Tellez, G.; Shivaramaiah, S.; Barta, J.; Hernandez-Velasco, X.; Hargis, B. Coccidiosis: Recent advancements in the immunobiology of Eimeria species, preventive measures, and the importance of vaccination as a control tool against these Apicomplexan parasites. Vet. Med. Res. Rep. 2014, 5, 23-34. [CrossRef]

10. Dalloul, R.A.; Lillehoj, H.S.; Shellem, T.A.; Doerr, J.A. Enhanced mucosal immunity against Eimeria acervulina in broilers fed a Lactobacillus-based probiotic. Poult. Sci. 2003, 82, 62-66. [CrossRef]

11. Lee, S.H.; Lillehoj, H.S.; Dalloul, R.A.; Park, D.W.; Hong, Y.H.; Lin, J.J. Influence of Pediococcus-based probiotic on coccidiosis in broiler chickens. Poult. Sci. 2007, 86, 63-66. [CrossRef]

12. Wang, X.; Peebles, E.D.; Kiess, A.S.; Wamsley, K.G.S.; Zhai, W. Effects of coccidial vaccination and dietary antimicrobial alternatives on the growth performance, internal organ development, and intestinal morphology of Eimeria-challenged male broilers. Poult. Sci. 2019, 98, 2054-2065. [CrossRef]

13. Elmusharaf, M.A.; Peek, H.W.; Nollet, L.; Beynen, A.C. The effect of an in-feed mannanoligosaccharide preparation (MOS) on a coccidiosis infection in broilers. Anim. Feed Sci. Technol. 2007, 134, 347-354. [CrossRef]

14. Craig, A.D.; Khattak, F.; Hastie, P.; Bedford, M.R.; Olukosi, O.A. Xylanase and xylo-oligosaccharide prebiotic improve the growth performance and concentration of potentially prebiotic oligosaccharides in the ileum of broiler chickens. Br. Poult. Sci. 2020, 61, 70-78. [CrossRef] [PubMed]

15. Craig, A.D.; Khattak, F.; Hastie, P.; Bedford, M.R.; Olukosi, O.A. The similarity of the effect of carbohydrase or prebiotic supplementation in broilers aged 21 days, fed mixed cereal diets and challenged with coccidiosis infection. PLoS ONE 2020, 15, 0229281. [CrossRef]

16. Olukosi, O.A.; Beeson, L.A.; Englyst, K.; Romero, L.F. Effects of exogenous proteases without or with carbohydrases on nutrient digestibility and disappearance of non-starch polysaccharides in broiler chickens. Poult. Sci. 2015, 94, 2662-2669. [CrossRef] [PubMed]

17. Lin, Y.; Olukosi, O.A. Qualitative and quantitative profiles of jejunal oligosaccharides and cecal short-chain fatty acids in broiler chickens receiving different dietary levels of fiber, protein and exogenous enzymes. J. Sci. Food Agric. 2021, 101, 5190-5201. [CrossRef] [PubMed]

18. Johnson, J.; Reid, W.M. Anticoccidial drugs: Lesion scoring techniques in battery and floor-pen experiments with chickens. Exp. Parasitol. 1970, 28, 30-36. [CrossRef]

19. Livak, K.J.; Schmittgen, T.D. Analysis of relative gene expression data using real-time quantitative PCR and the 2- $\Delta \Delta C T$ method. Methods 2001, 25, 402-408. [CrossRef] 
20. Nisbet, D.J.; Corrier, D.E.; Scanlan, C.M.; Hollister, A.G.; Beier, R.C.; DeLoach, J.R. Effect of a Defined Continuous-Flow Derived Bacterial Culture and Dietary Lactose on Salmonella typhimurium Colonization in Broiler Chickens. Avian Dis. 1993, $37,1017$. [CrossRef]

21. Teng, P.Y.; Yadav, S.; de Souza Castro, F.L.; Tompkins, Y.H.; Fuller, A.L.; Kim, W.K. Graded Eimeria challenge linearly regulated growth performance, dynamic change of gastrointestinal permeability, apparent ileal digestibility, intestinal morphology, and tight junctions of broiler chickens. Poult. Sci. 2020, 99, 4203-4216. [CrossRef]

22. Teng, P.-Y.; Choi, J.; Tompkins, Y.; Lillehoj, H.; Kim, W. Impacts of increasing challenge with Eimeria maxima on the growth performance and gene expression of biomarkers associated with intestinal integrity and nutrient transporters. Vet. Res. 2021, 52, 81. [CrossRef]

23. Kim, E.; Leung, H.; Akhtar, N.; Li, J.; Barta, J.R.; Wang, Y.; Yang, C.; Kiarie, E. Growth performance and gastrointestinal responses of broiler chickens fed corn-soybean meal diet without or with exogenous epidermal growth factor upon challenge with Eimeria. Poult. Sci. 2017, 96, 3676-3686. [CrossRef] [PubMed]

24. Park, I.; Lee, Y.; Goo, D.; Zimmerman, N.P.; Smith, A.H.; Rehberger, T.; Lillehoj, H.S. The effects of dietary Bacillus subtilis supplementation, as an alternative to antibiotics, on growth performance, intestinal immunity, and epithelial barrier integrity in broiler chickens infected with Eimeria maxima. Poult. Sci. 2020, 99, 725-733. [CrossRef] [PubMed]

25. Kipper, M.; Andretta, I.; Lehnen, C.R.; Lovatto, P.A.; Monteiro, S.G. Meta-analysis of the performance variation in broilers experimentally challenged by Eimeria spp. Vet. Parasitol. 2013, 196, 77-84. [CrossRef]

26. Walk, C.L.; Cowieson, A.J.; Remus, J.C.; Novak, C.L.; McElroy, A.P. Effects of dietary enzymes on performance and intestinal goblet cell number of broilers exposed to a live coccidia oocyst vaccine. Poult. Sci. 2011, 90, 91-98. [CrossRef] [PubMed]

27. Bozkurt, M.; Aysul, N.; Küçükyilmaz, K.; Aypak, S.; Ege, G.; Çatli, A.U.; Akşit, H.; Çöven, F.; Seyrek, K.; Çinar, M. Efficacy of in-feed preparations of an anticoccidial, multienzyme, prebiotic, probiotic, and herbal essential oil mixture in healthy and Eimeria spp.-infected broilers. Poult. Sci. 2014, 93, 389-399. [CrossRef] [PubMed]

28. Parker, J.; Oviedo-Rondón, E.O.; Clack, B.A.; Clemente-Hernández, S.; Osborne, J.; Remus, J.C.; Kettunen, H.; Mäkivuokko, H.; Pierson, E.M. Enzymes as feed additive to aid in responses against Eimeria species in coccidia-vaccinated broilers fed corn-soybean meal diets with different protein levels. Poult. Sci. 2007, 86, 643-653. [CrossRef]

29. Liu, J.; Teng, P.-Y.; Kim, W.K.; Applegate, T.J. Assay considerations for fluorescein isothiocyanate-dextran (FITC-d): An indicator of intestinal permeability in broiler chickens. Poult. Sci. 2021, 100, 101202. [CrossRef]

30. Ulluwishewa, D.; Anderson, R.C.; McNabb, W.C.; Moughan, P.J.; Wells, J.M.; Roy, N.C. Regulation of tight junction permeability by intestinal bacteria and dietary components. J. Nutr. 2011, 141, 769-776. [CrossRef] [PubMed]

31. Castro, F.L.S.; Teng, P.Y.; Yadav, S.; Gould, R.L.; Craig, S.; Pazdro, R.; Kim, W.K. The effects of L-Arginine supplementation on growth performance and intestinal health of broiler chickens challenged with Eimeria spp. Poult. Sci. 2020, 99, 5844-5857. [CrossRef]

32. Poritz, L.S.; Harris, L.R.; Kelly, A.A.; Koltun, W.A. Increase in the tight junction protein claudin-1 in intestinal inflammation. Dig. Dis. Sci. 2011, 56, 2802-2809. [CrossRef] [PubMed]

33. Pope, J.L.; Ahmad, R.; Bhat, A.A.; Washington, M.K.; Singh, A.B.; Dhawan, P. Claudin-1 overexpression in intestinal epithelial cells enhances susceptibility to adenamatous polyposis coli-mediated colon tumorigenesis. Mol. Cancer 2014, 13, 167. [CrossRef] [PubMed]

34. Garcia-Hernandez, V.; Quiros, M.; Nusrat, A. Intestinal epithelial claudins: Expression and regulation in homeostasis and inflammation. Ann. N. Y. Acad. Sci. 2017, 1397, 66-79. [CrossRef]

35. Liu, D.; Guo, S.; Guo, Y. Xylanase supplementation to a wheat-based diet alleviated the intestinal mucosal barrier impairment of broiler chickens challenged by clostridium perfringens. Avian Pathol. 2012, 41, 291-298. [CrossRef] [PubMed]

36. He, X.; Yu, B.; He, J.; Huang, Z.; Mao, X.; Zheng, P.; Luo, Y.; Luo, J.; Wang, Q.; Wang, H.; et al. Effects of xylanase on growth performance, nutrients digestibility and intestinal health in weaned piglets. Livest. Sci. 2020, 233, 103940. [CrossRef]

37. Su, S.; Miska, K.B.; Fetterer, R.H.; Jenkins, M.C.; Wong, E.A. Expression of digestive enzymes and nutrient transporters in Eimeria-challenged broilers. Exp. Parasitol. 2015, 150, 13-21. [CrossRef]

38. Mueckler, M.; Thorens, B. The SLC2 (GLUT) family of membrane transporters. Mol. Asp. Med. 2013, 34, 121-138. [CrossRef]

39. Röder, P.V.; Geillinger, K.E.; Zietek, T.S.; Thorens, B.; Koepsell, H.; Daniel, H. The role of SGLT1 and GLUT2 in intestinal glucose transport and sensing. PLoS ONE 2014, 9, e89977. [CrossRef]

40. Awad, W.A.; Aschenbach, J.R.; Ghareeb, K.; Khayal, B.; Hess, C.; Hess, M. Campylobacter jejuni influences the expression of nutrient transporter genes in the intestine of chickens. Vet. Microbiol. 2014, 172, 195-201. [CrossRef]

41. Verrey, F.; Closs, E.I.; Wagner, C.A.; Palacin, M.; Endou, H.; Kanai, Y. CATs and HATs: The SLC7 family of amino acid transporters. Pflugers Arch. Eur. J. Physiol. 2004, 447, 532-542. [CrossRef]

42. Allen, P.C.; Fetterer, R.H. Effect of Eimeria acervulina infections on plasma L-arginine. Poult. Sci. 2000, 79, 1414-1417. [CrossRef] [PubMed]

43. Miska, K.B.; Fetterer, R.H. Molecular and cellular biology: The effect of Eimeria maxima infection on the expression of amino acid and sugar transporters aminopeptidase, as well as the di- and tri-peptide transporter PepT1, is not solely due to decreased feed intake. Poult. Sci. 2018, 97, 1712-1721. [CrossRef] [PubMed] 
44. Hosseini, S.M.; Manafi, M.; Nazarizadeh, H. Effects of xylanase supplementation and citric acid on performance, ileal nutrients digestibility, and gene expression of intestinal nutrient transporters in broilers challenged with Clostridium perfringens. Poult. Sci. 2017, 54, 149-156. [CrossRef]

45. Craig, A.D.; Bedford, M.R.; Hastie, P.; Khattak, F.; Olukosi, O.A. The effect of carbohydrases or prebiotic oligosaccharides on growth performance, nutrient utilisation and development of small intestine and immune organs in broilers fed nutrient-adequate diets based on either wheat or barley. J. Sci. Food Agric. 2019, 99, 3246-3254. [CrossRef] [PubMed]

46. Morgan, N.K.; Wallace, A.; Bedford, M.R.; Hawking, K.L.; Rodrigues, I.; Hilliar, M.; Choct, M. In vitro versus in situ evaluation of xylan hydrolysis into xylo-oligosaccharides in broiler chicken gastrointestinal tract. Carbohydr. Polym. 2020, $230,115645$. [CrossRef]

47. Macfarlane, G.T.; Gibson, G.R.; Cummings, J.H. Comparison of fermentation reactions in different regions of the human colon. J. Appl. Bacteriol. 1992, 72, 57-64. [CrossRef] [PubMed]

48. Windey, K.; de Preter, V.; Verbeke, K. Relevance of protein fermentation to gut health. Mol. Nutr. Food Res. 2012, 56, 184-196. [CrossRef]

49. Zhou, Z.; Nie, K.; Huang, Q.; Li, K.; Sun, Y.; Zhou, R.; Wang, Z.; Hu, S. Changes of cecal microflora in chickens following Eimeria tenella challenge and regulating effect of coated sodium butyrate. Exp. Parasitol. 2017, 177, 73-81. [CrossRef] [PubMed]

50. Flint, H.J.; Duncan, S.H. Bacteroides and Prevotella. In Encyclopedia of Food Microbiology, 2nd ed.; Elsevier Inc.: Amsterdam, The Netherlands, 2014; pp. 203-208, ISBN 9780123847331.

51. Neis, E.P.J.G.; Dejong, C.H.C.; Rensen, S.S. The role of microbial amino acid metabolism in host metabolism. Nutrients 2015, 7, 2930-2946. [CrossRef] [PubMed]

52. Coffey, J.C.; Bolger, J. Microbiota in pouchitis and de novo crohn's disease of the ileal pouch. In Pouchitis and Ileal Pouch Disorders: A Multidisciplinary Approach for Diagnosis and Management; Academic Press: Cambridge, MA, USA, 2018; pp. 119-127, ISBN 9780128094020. 